\title{
KLAIPĖDOS MIESTO IR RAJONO 10-12 KLASIŲ MOKINIŲ RIZIKINGA ELGSENA: PSICHOAKTYVIŲJŲ MEDŽIAGŲ VARTOJIMAS
}

\author{
Neringa Strazdienė ${ }^{1}$, Birutė Strukčinskiene் ${ }^{1}$, Vaiva Strukčinskaite் ${ }^{2}$, Ineta Pačiauskaitė ${ }^{1}$, \\ Marina Prokofjeva ${ }^{1}$, Sigitas Griškonis ${ }^{1,3}$ \\ ${ }^{1}$ Klaipédos universitetas, ${ }^{2}$ Vilniaus kolegija, ${ }^{3}$ Klaipédos universitetiné ligoniné
}

Raktažodžiai: Klaipedos miestas, Klaipėdos rajonas, mokiniai, paaugliai, jaunimas, rizikinga elgsena, psichoaktyviosios medžiagos.

\begin{abstract}
Santrauka
Daugelio ligų ir sutrikimų priežastis - rizikingas elgesys, kuris kelia grèsmę žmogaus sveikatai, gerovei, ateities raidai bei sėkmei. Ypač svarbu, kad paauglysteje naujos patirtys netaptų rizikinga elgsena, o besiformuojantys gyvensenos ịpročiai taptų poreikiu elgtis sveikai. Straipsnyje analizuojami Klaipedos miesto ir rajono 1012 klasių mokinių rizikingos elgsenos - psichoaktyviujų medžiagų: tabako gaminių ir (ar) elektroninių cigarečių, alkoholio, narkotinių medžiagų vartojimo aspektai. Pasirinkta kiekybinio tyrimo strategija, taikyta apklausa raštu. Buvo apklausta 260 Klaipėdos miesto ir rajono 10-12 klasès mokinių nuo 16 iki 19 metų. Statistinei duomenų analizei naudota SPSS programa (versija 23.0). Statistiniam reikšmingumui tikrinti taikytas Chi kvadrato $\left(\chi^{2}\right)$ kriterijus. Duomenys statistiškai reikšmingi, kai p $<0,05$. Tyrimo rezultatai parodè, kad psichoaktyviąsias medžiagas dauguma paauglių pirmą kartą pavartojo būdami 1316 metų, o dalis paauglių - 7-12 metų. Dauguma paauglių nevartojo narkotinių medžiagų, tačiau vartojo alkoholị, o beveik pusè - rūkè. Vaikinai reikšmingai dažniau vartojo alkoholinius gèrimus bei narkotines medžiagas, nei merginos. Mieste ir rajone (kaime) gyvenantys paaugliai psichoaktyviąsias medžiagas vartojo panašiai. Paauglius vartoti psichoaktyviąsias medžiagas paskatino bendraamžiai. Apie pusė paauglių mano, kad psichoaktyviosios medžiagos padeda atsipalaiduoti.
\end{abstract}

\section{Ivadas}

Pasaulio sveikatos organizacija (PSO) teigia, kad daugelio ligų ir sutrikimų priežastis - rizikingas elgesys, kuris tiesiogiai ar netiesiogiai kelia grèsmę žmogaus sveikatai, gerovei ir ateities raidai bei sèkmei [1]. Statistika rodo, kad tarp dešimties pagrindinių ankstyvos mirties priežasčių yra toks elgesys kaip rūkymas, piktnaudžiavimas alkoholiu, mažas fizinis aktyvumas, nesveika mityba, nesaugūs lytiniai santykiai, gydytojų rekomendacijų nesilaikymas [2]. Kiti rizikingo elgesio tipai - psichoaktyviujų medžiagų vartojimas, vairavimas apsvaigus nuo alkoholio, saugos diržų nesegejimas automobilyje ir kai kurie kiti taip pat yra susiję su ilgalaikiais ar trumpalaikiais sveikatos sutrikimais [3].

Paauglystė yra ypatingas žmogaus gyvenimo tarpsnis. Jo metu vyksta intensyvus savęs suvokimas, savo vaizdo susidarymas, gyvenimo pozicijos ieškojimas, savo tapatybės ịtvirtinimas [4]. Šiame amžiuje jaunas žmogus nori viską išbandyti, patirti, pajusti naujus jausmus bei išbandyti kūno galimybes [5], todèl svarbu, kad naujos patirtys netaptų rizikinga elgsena, o besiformuojantys gyvensenos icpročiai taptų poreikiu elgtis sveikai.

Paaugliu rizikingos elgsenos problema nèra nauja, bet ypač aktuali šiandienos vaikų ir jaunimo gyvensenos kontekste. Kiekvienas laikmetis kelia naujus paauglių rizikingos elgsenos iššūkius, tad svarbu tirti šios problemos mastą ir situaciją, nes tai gali padèti numatyti vaikų ir jaunų žmonių rizikingos elgsenos problemos spendimo galimybes bei planuoti ir igyvendinti prevencines priemones.

Vaikų, paauglių, jaunų žmonių rizikingos elgsenos problemas įvairiais aspektais tyrè daugelis šalies ir užsienio mokslininkų [6-17]. Tarptautiniai tyrimai rodo, kad rizikinga elgsena glaudžiai susijusi su psichoaktyviụjų medžiagų vartojimu (piktnaudžiavimu alkoholiu, narkotinèmis medžiagomis, rūkymu) [18-24]. Žalingas alkoholio ir narkotinių medžiagų vartojimas bei rūkymas yra didelè sveikatos ir socialinè problema, kuriai spręsti taikomos minimalios ir maksimalios intervencijos [6-8]. Priklausomybę sukeliančių medžiagų vartojimas - viena didžiausių paauglių sveikatos problemų. İvairūs moksliniai tyrimai įrodè, kad alkoholio vartojimas ir rūkymas yra pavojingi jaunų 
žmonių sveikatai ir kelia pavojų visuomenès saugai [25].

Lietuvos paaugliai dažniau pirmą kartą pasigeria būdami jaunesni nei 13 metų, lyginant su kitų Europos šalių paaugliais. Be to, psichoaktyviujjų medžiagų vartojimas stebimas vis jaunesnio amžiaus vaikams $[25,26]$. Mūsų šalyje berniukai alkoholi vartoja dažniau nei mergaitès, vaikų grupejje rūkymas taip pat labiau paplitęs tarp berniukų. Deja, jauniausi rūkaliai, kuriems patarimas mesti rūkius galètų duoti didžiausią sveikatos išsaugojimo efektą, toki gydytojo patarimą gauna rečiausiai [26]. Kanapių produktų mokiniai vartoja daugiau, nei kitų narkotinių medžiagų. Tarp Lietuvos mokinių didèja kanapių vartojimas, jaunèja vartojančių mokinių amžius ir daugèja kanapių produktus vartojančių merginų [25].

Vaikų ir paauglių rūkymas, alkoholio, ịvairių narkotinių medžiagų vartojimas yra svarbūs klausimai, kuriuos bando spręsti mokslininkai, visuomenès sveikatos specialistai, medikai, pedagogai, psichologai, nevyriausybinių organizacijų atstovai, policijos darbuotojai. Visuomenès sveikatos ekspertai skatina aktyviau taikyti mokslinius tyrimus, analizuoti problemos mastą, nagrinèti, kas galètų efektyviau mažinti vaikų, paauglių ir jaunų žmonių psichoaktyviujų medžiagų vartojimą. Moksliniai tyrimai apie rizikingą jaunų žmonių elgesị gali padèti identifikuoti problemas, įvertinti galimas prevencines priemones, formuoti sveikatos politiką bei pasiūlyti prevencines strategijas.

Tyrimo tikslas - analizuoti Klaipedos miesto ir rajono 10-12 klasių mokinių rizikingą elgseną ir psichoaktyviųjų medžiagų (tabako gaminių ir (ar) elektroninių cigarečių, alkoholio, narkotinių medžiagų) vartojimą.

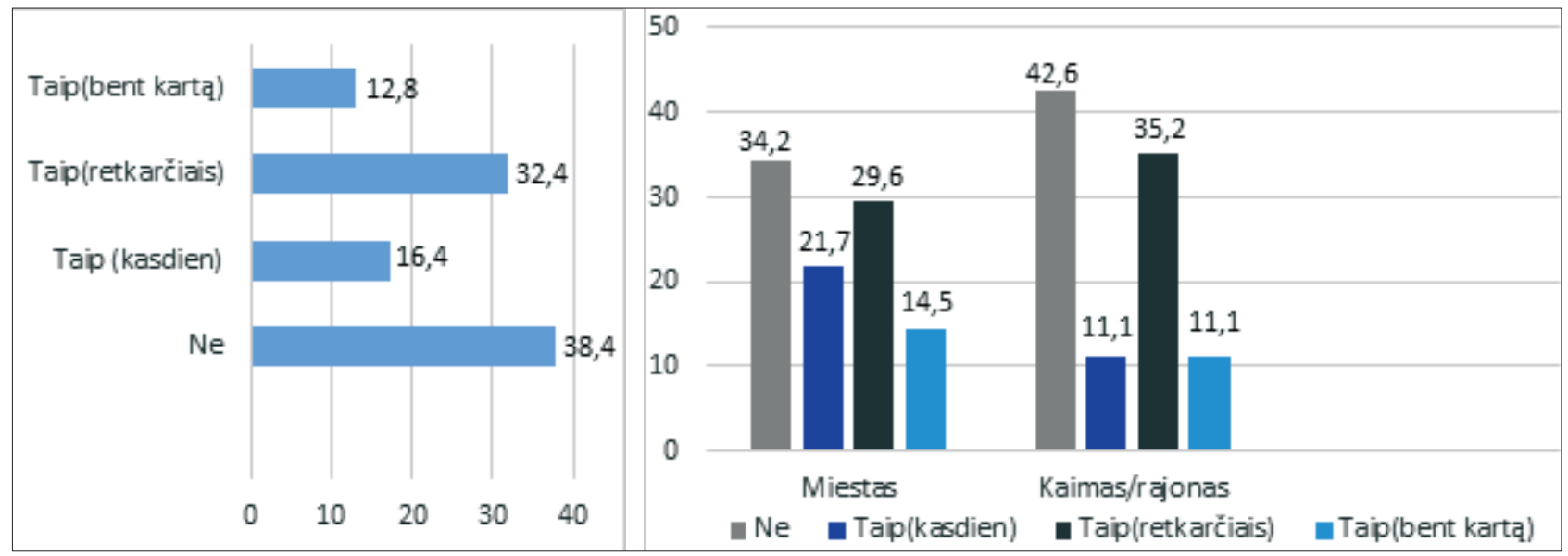

1a pav. Visos tiriamųjų grupès duomenys

1 b pav. Duomenų pasiskirstymas pagal vietovę

1 pav. Mokinių tabako gaminių vartojimas per pastaruosius 12 mènesių (proc.)

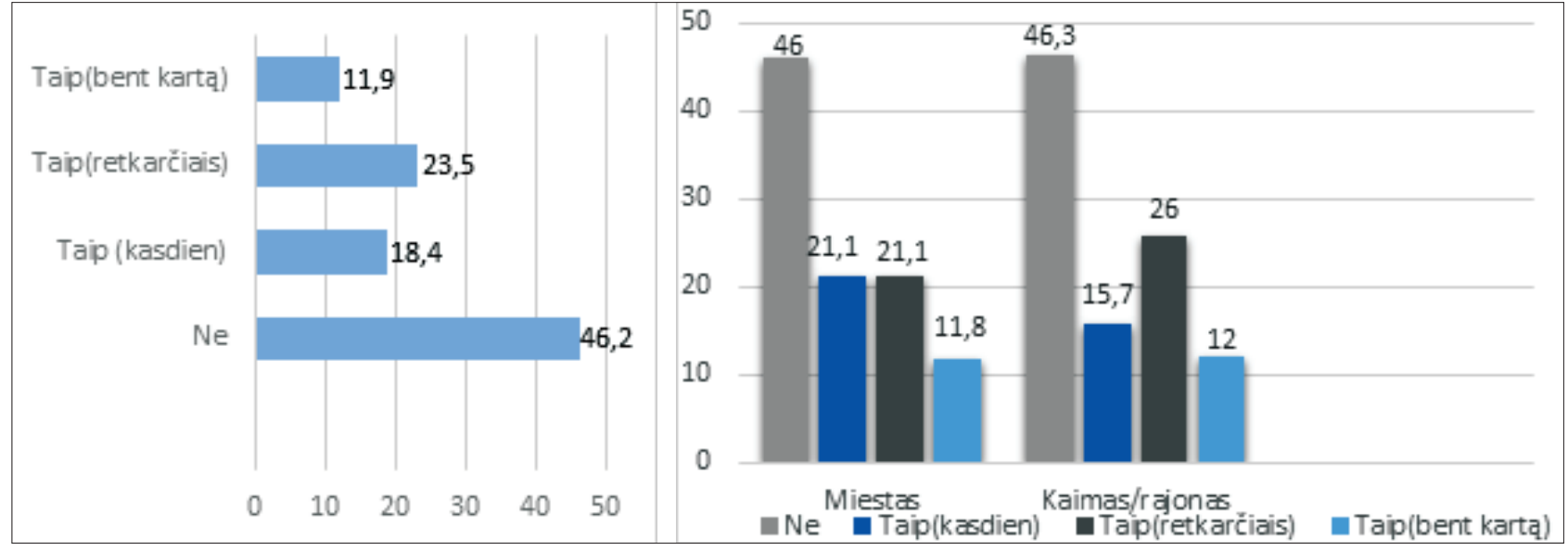

2a pav. Visos tiriamųjų grupès duomenys

2b pav. Duomenų pasiskirstymas pagal vietovę

2 pav. Mokinių tabako gaminių vartojimas per pastarąsias 30 dienų (proc.) 


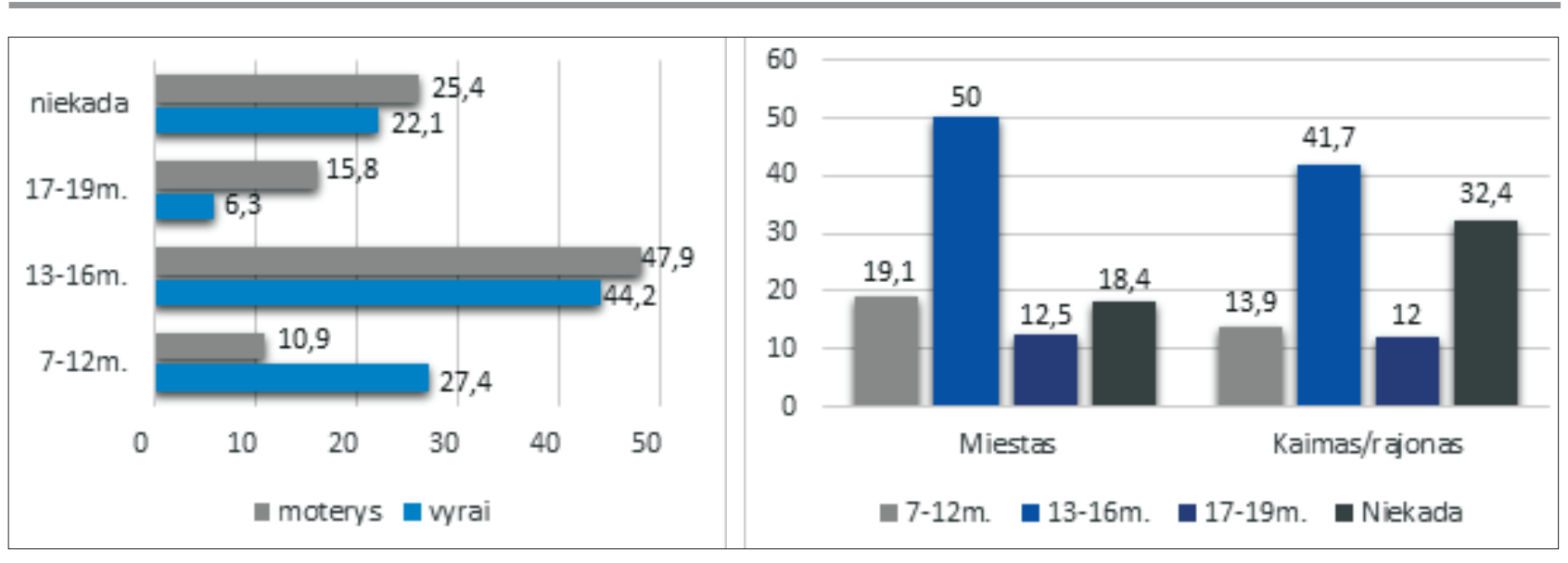

3a pav. Duomenų pasiskirstymas pagal lytị

3b pav. Duomenų pasiskirstymas pagal vietovę

3 pav. Mokinių, pirmą kartą pabandžiusių rūkyti tabako gaminius ir (ar) elektronines cigaretes, amžius (proc.)

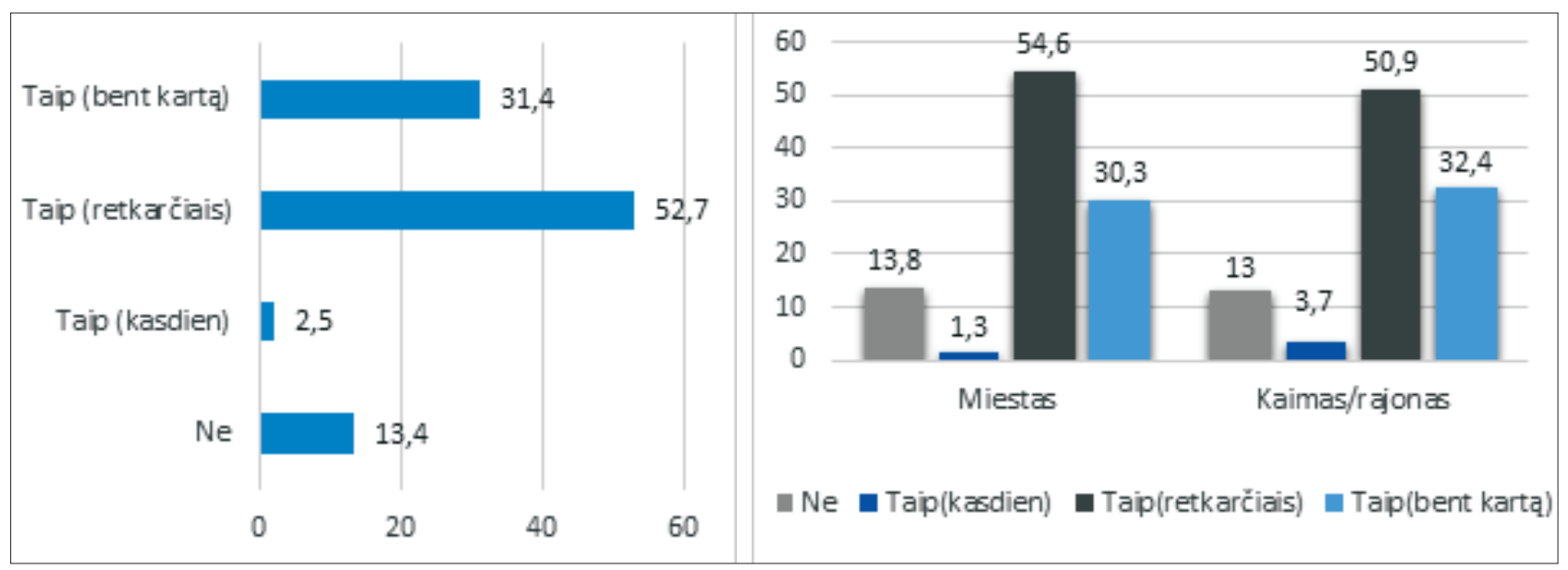

4a pav. Visos tiriamųų grupès duomenys

4b pav. Duomenų pasiskirstymas pagal vietovę

4 pav. Mokinių alkoholio vartojimas per pastaruosius 12 mèn. (proc.)

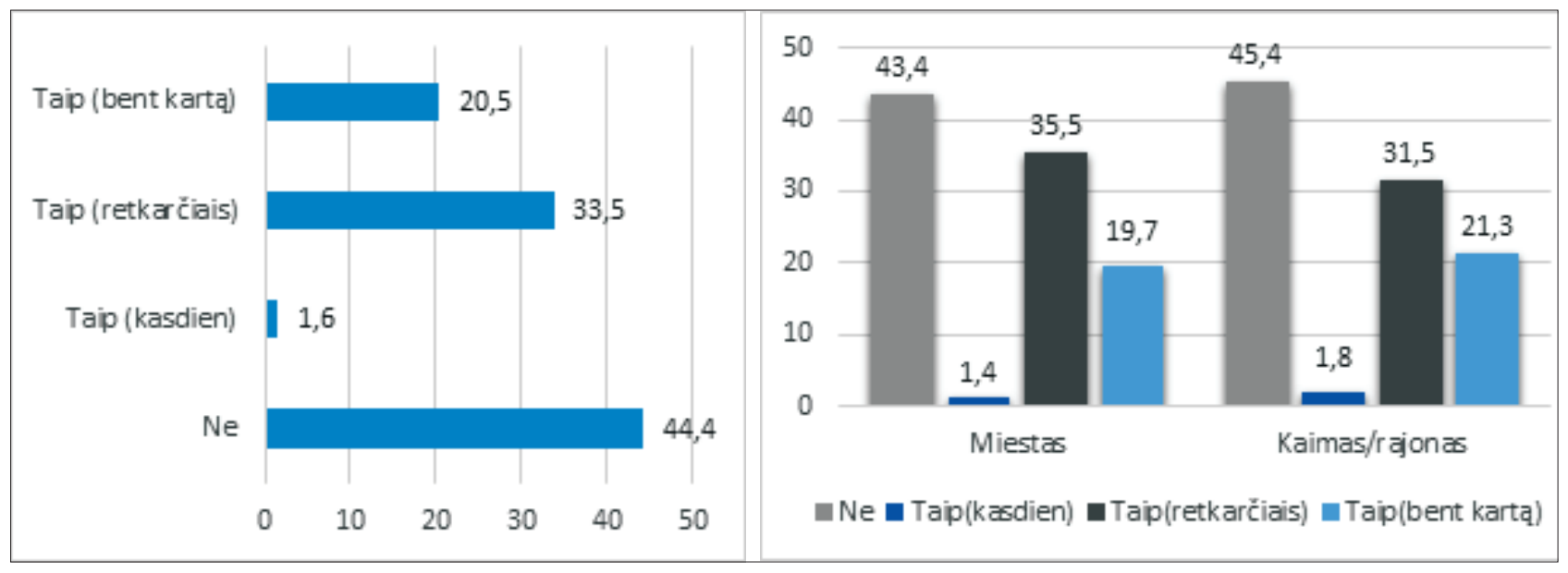

5a pav. Visos tiriamųų grupès duomenys

5b pav. Duomenų pasiskirstymas pagal vietovę 5 pav. Mokinių alkoholio vartojimas per pastarąsias 30 dienų (proc.) 


\section{Tyrimo medžiaga ir metodai}

Siekiant atskleisti paauglių rizikingos elgsenos paplitimo situaciją Klaipédos miesto ir rajono gimnazijose, pasirinkta kiekybinio tyrimo strategija, taikyta apklausa raštu. Klausimyną sudare 25 klausimai, parengti remiantis Mokyklinio amžiaus vaikų gyvensenos tyrimu (2016) [27]. Straipsnyje analizuojama dalis visų surinktų tyrimo duomenų. Tyrimo kontingentą sudarè moksleiviai iš Klaipedos miesto ir Klaipėdos rajono gimnazijų. Tyrimo dalyviai - 10-12 klasių mokiniai nuo 16 iki 19 metų. Buvo apklausta 260 respondentų: 152 mokiniai iš Klaipedos miesto (58,5 proc.) ir 108 (41,5 proc.) mokiniai iš Klaipedos rajono gimnazijų. Iš visų apklaustujų 95 buvo vaikinai (36,5 proc.) ir 165 merginos (63,5 proc.). Tyrimas atliktas 2019 metais. Tyrimo procedūra ir tyrimo atlikimas buvo suderinti su mokyklų vadovais, gautas jų leidimas atlikti tyrimą. Statistinei duomenų analizei atlikti naudota SPSS programa (versija 23.0). Statistiniam reikšmingumui tikrinti taikytas Chi kvadrato $\left(\chi^{2}\right)$ kriterijus, Duomenys statistiškai reikšmingi, kai $p<0,05$.

\section{Tyrimo rezultatai ir ju aptarimas}

Analizuojant 10-12 klasès moksleivių rizikingo elgesio paplitimą, domètasi, ar moksleiviai per pastaruosius 12 mènesių buvo bent kartą rūkę tabako gaminius ir (ar) elektronines cigaretes (1 pav.).

Tyrimo rezultatai atskleide, kad daugiau kaip trečdalis $(38,4$ proc.) mokinių nerūkè, o apie du trečdaliai rūkẻ tabako gaminius ir (ar) elektronines cigaretes: kasdien (16,4 proc.), retkarčiais (32,4 proc.), ar bent kartą per pastaruosius 12 mènesiu (12,8 proc.). Šiek tiek daugiau (42,6 proc.) nerūkiusių 10-12 klasių moksleivių buvo kaimo (rajono) mokyklose, nei miesto (34,2 proc.) mokyklose.

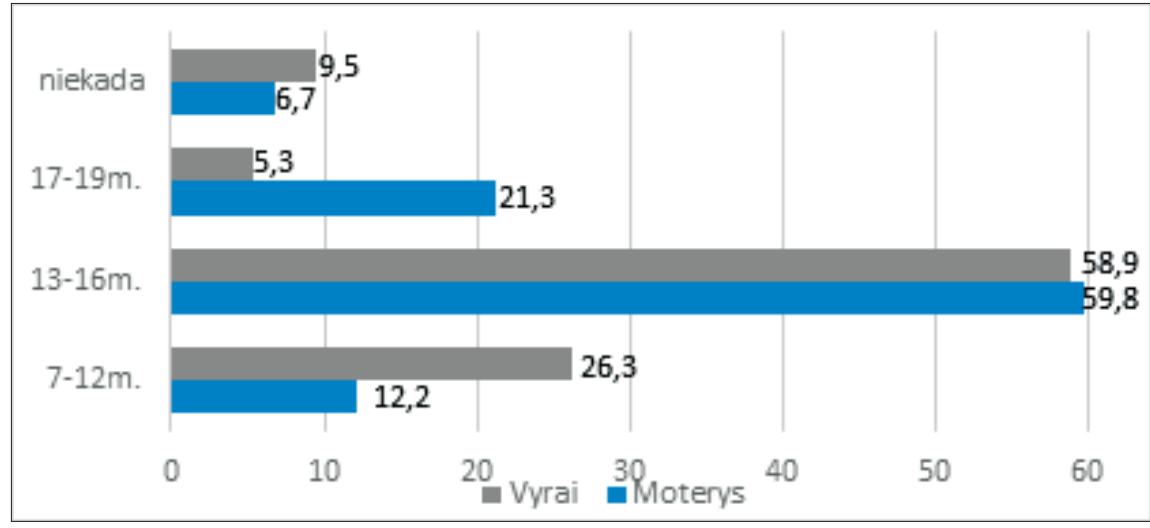

6 pav. Mokinių amžius, pirmą kartą pabandžiusių alkoholinių gėrimų (proc.)

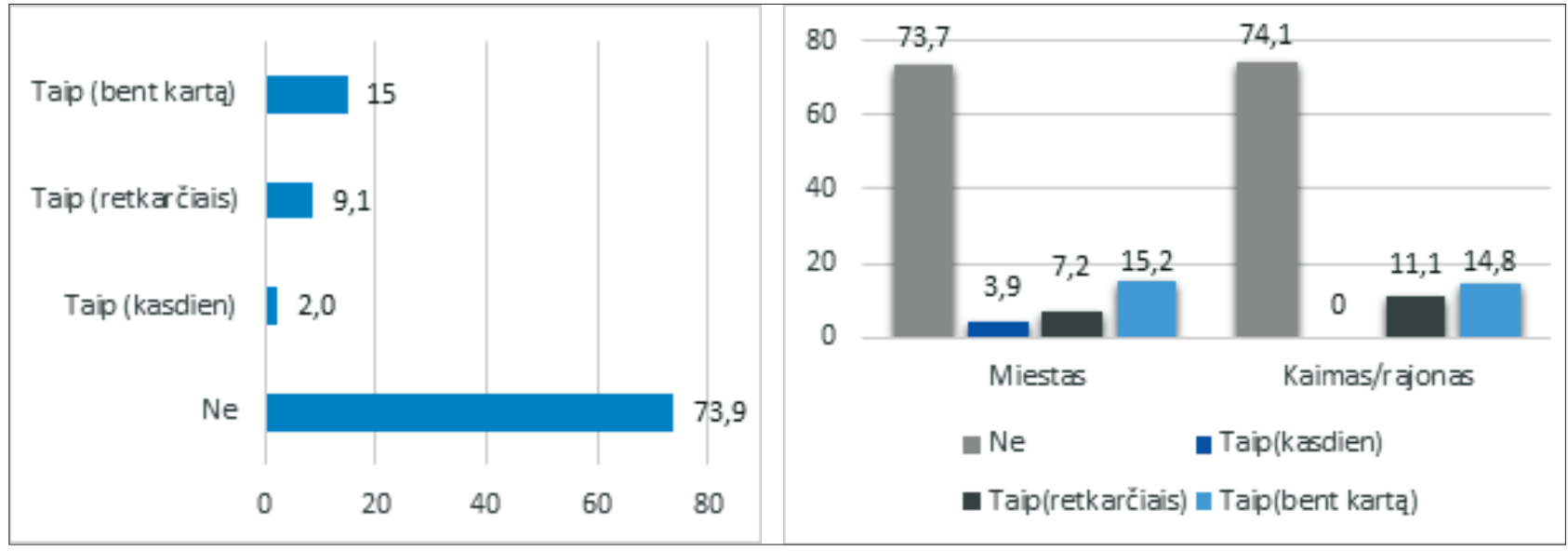

7a pav. Visos tiriamujų grupès duomenys

7b pav. Duomenų pasiskirstymas pagal vietovę

7 pav. Mokinių narkotinių medžiagų vartojimas per pastaruosius 12 ménesių (proc.) 
Domètasi, ar 10-12 klasės mokiniai per pastarąsias 30 dienų bent kartą rūké tabako gaminius ir (ar) elektronines cigaretes (2 pav.).

Tyrimas parodè, jog beveik pusè (46,2 proc.) mokiniu nerūkè ir apie pusè rūkè tabako gaminius ir (ar) elektronines cigaretes: kasdien (18,4 proc.), retkarčiais (23,5 proc.), bent kartą per pastarąsias 30 dienų (11,9 proc.). Lyginant gautus duomenis vietovès atžvilgiu, atsakiusiujų skaičius pasiskirstė tolygiai: apie pusė miesto ( 46,0 proc.) ir beveik pusė kaimo (rajono) (46,3 proc.) mokinių nerūkè ir apie pusè miesto ( 54,0 proc.) bei puse kaimo (rajono) (53,7 proc.) mokinių rūkè per pastarąsias 30 dienų.

Moksleivių klausėme, kiek jiems buvo metų, kai pirmą kartą pabandè rūkyti tabako gaminius ir (ar) elektronines cigaretes ( 3 pav.).

Tyrimo rezultatai atskleide, kad beveik pusė merginų (47,9 proc.) ir panašiai tiek pat vaikinų (44,2 proc.) pabande rūkyti būdami 13-16 metų. Beveik trečdalis (27,4 proc.) vaikinų ir apie dešimtadalis (10,9 proc.) merginų pirmą kartą bandè rūkyti būdami 7-12 metų. Gauti statistiškai reikšmingi $(p<0,05)$ duomenys amžiaus aspektu rodo, jog dažniausiai paaugliai pradeda rūkyti ir (ar) vartoti elektronines cigaretes būdami 13-16 metų $\left(\chi^{2}=14,471,11 \mathrm{~s}=3, \mathrm{p}=0,002\right)$. Lyginant gautus duomenis vietovès atžvilgiu, išryškèjo, jog daugiausia -50 proc. miesto ir 41,7 proc. kaimo (rajono) mokinių pirmą kartą pabandè rūkyti būdami 13-16 metų.

Tyrimu siekème nustatyti, ar 10-12 klasių mokiniai bent kartą vartojo kokị nors alkoholini gèrimą per pastaruosius 12 mèn. (4 pav.).

Tyrimo duomenys rodo, jog tik apie dešimtadalis $(13,4$ proc.) šio amžiaus mokinių nevartojo alkoholio per pastaruosius 12 ménesių. Apie pusè (52,7 proc.) apklaustujų alkoholi vartojo retkarčiais, trečdalis (31,4 proc.) - bent kartą, o 2,5 proc. - kasdien. Lyginant gautus duomenis tarp apklaustų miesto ir kaimo (rajono) moksleivių didelių skirtumų neišryškèjo - gautos panašios procentinès raiškos, tačiau 3,7 proc. kaimo (rajono) moksleivių pažymèjo, jog vartojo alkoholį kasdien, o kasdien vartojančių alkoholi miesto moksleivių buvo 1,3 procento. Rasti statistiškai reikšmingi skirtumai tarp vaikinų ir merginų alkoholio vartojimo per pastaruosius 12 mènesiu ( $p<0,05)$. Vaikinai per pastaruosius 12 mèn. dažniau nei merginos bent kartą vartojo koki nors alkoholini gèrimą $\left(\chi^{2}=9,837,11 \mathrm{~s}=3, \mathrm{p}=0,02\right)$.

Siekème išsiaiškinti, ar 10-12 klasių mokiniai bent kartą vartojo kokị nors alkoholinị gėrimą per pastarąsias 30 dienų (5 pav.).

Niekada alkoholio nevartojo 44,4 proc. moksleiviu per pastarąsias 30 dienų. Bent kartą vartojo apie penktadalis (20,5 proc.), retkarčiais - apie trečdalis (33,5 proc.) ir kasdien vartojo 1,6 proc. mokinių per pastarąsias 30 dienų. Lyginant gautus duomenis tarp miesto ir kaimo (rajono) 10-12 klasių mokinių, gautos panašios procentinès raiškos. Vaikinai reikšmingai dažniau bent kartą vartojo kokị nors alkoholini gèrimą per pastarąsias 30 dienų, nei merginos $\left(\chi^{2}=8,733,1 l s=3, p=0,03\right)$.

Tyrimu siekème sužinoti, kokio amžiaus buvo mokiniai, kai pirmą kartą pavartojo alkoholinių gèrimų (6 pav.).

Tyrimo rezultatai parodè, kad apie pusè vaikinų $(58,9$ proc.) ir pusé merginų (59,8 proc.) alkoholinių gèrimų pirmą kartą pavartojo būdami 13-16 metų. Tyrimas atskleidè, kad nemaža paauglių dalis - vaikinų (26,3 proc.) ir merginų (12,2 proc.) pirmą kartą alkoholio paragavo būdami 7-12 metų $\left(\chi^{2}=17,575,11 s=3, p=0,001\right)$.

Siekėme ištirti, ar mokiniai bent kartą vartojo kanapių produktų ar kitą narkotinę medžiagą per pastaruosius 12 ménesių (7 pav.).

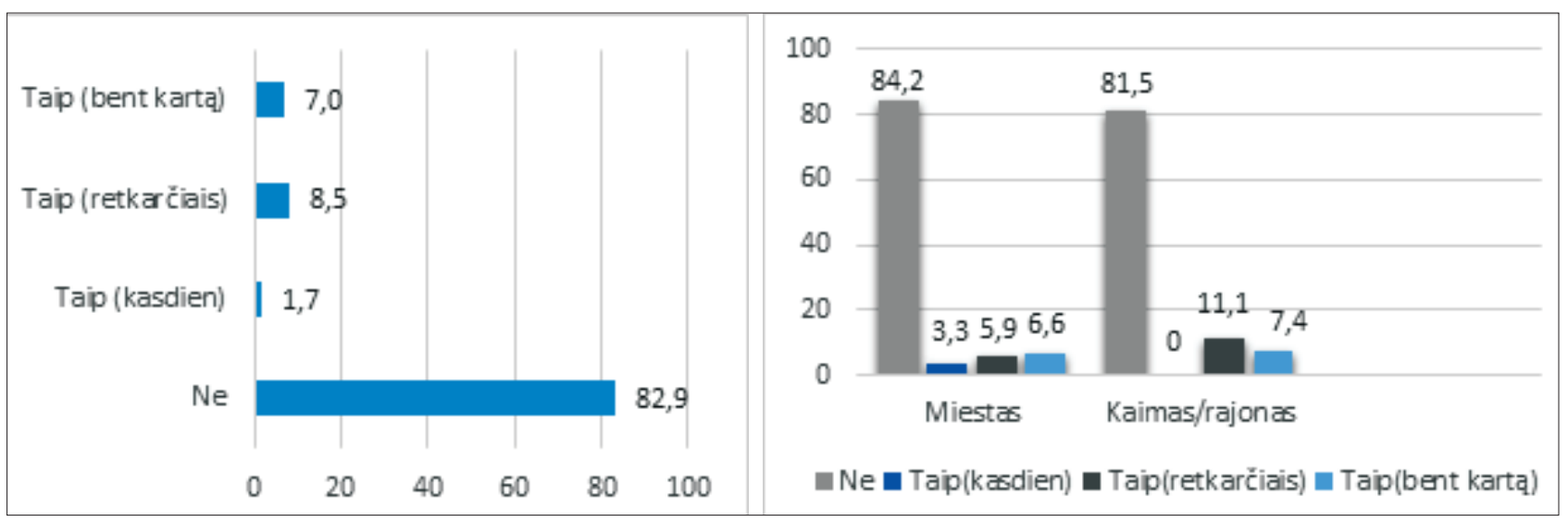

8a pav. Visos tiriamųų grupès duomenys

8b pav. Duomenų pasiskirstymas pagal vietovę 8 pav. Mokinių narkotinių medžiagų vartojimas per pastarąsias 30 dienų (proc.) 
Per pastaruosius 12 mėnesių visiškai nevartojo narkotinių medžiagų 73,9 proc. mokinių. Bent kartą per pastaruosius 12 mènesių narkotines medžiagas vartojo 15 proc. paauglių, retkarčiais $-9,1$ proc., kasdien $-2,0$ proc. respondentu. Net 3,9 proc. miesto paauglių nurodè kasdien vartoję narkotines medžiagas per pastaruosius 12 mènesių, o tarp kaimo (rajono) mokinių kasdien vartojančių narkotines medžiagas per pastaruosius 12 mèn. nebuvo. Gauti statistiškai reikšmingi $(p<0,05)$ skirtumai lyties aspektu: vaikinai dažniau nei merginos bent kartą vartojo kanapių produktus ar kitą narkotinę medžiagą per pastaruosius 12 mènesių $\left(\chi^{2}=16,202,11 s=3, p=0,001\right)$.

Mokinių klauseme, ar jie bent kartą vartojo kanapių produktų (marihuanos, hašišo, kanapių (,žolès") ar kitų narkotinių medžiagų per pastarąsias 30 dienų ( 8 pav.).

Moksleivių narkotinių medžiagų vartojimo per pastarąsias 30 dienų rezultatai rodo, jog visiškai narkotinių medžiagų nevartojo 82,9 proc. mokinių. Bent kartą vartojo 7,0 proc., retkarčiais $-8,5$ proc., kasdien 1,7 proc. apklaustujų. Net 3,3 proc. miesto mokinių teigè, jog kasdien vartojo narkotines medžiagas per pastarąsias 30 dienų, tačiau kaime (rajone) tokių mokinių nebuvo. Statistiškai reikšmingi $(\mathrm{p}<0,05)$ rezultatai rodo, kad vaikinai dažniau nei merginos bent kartą vartojo kanapių gaminius ar kitą narkotinę medžiagą per pastarąsias 30 dienų $\left(\chi^{2}=16,083,11 s=3, p=0,001\right)$.

10-12 klasių mokinių klausėme, kada pirmą kartą jie pavartojo narkotines medžiagas ( 9 pav.).

Daugiau kaip pusė vaikinų ( 60,0 proc.) ir merginų (67,7 proc.) atsakè, jog niekada nevartojo narkotinių medžiagų. 24,2 proc. vaikinų ir 15,8 proc. merginų pirmą kartą pavartojo narkotines medžiagas būdami 13-16 metų, o 14,7 proc. vaikinų ir 12,1 proc. merginų - būdami 17-19 metų.

Tyrimu siekta išsiaiškinti, kas pirmą kartą paskatino paauglius vartoti psichoaktyviąsias medžiagas (10 pav.).

Daugiau kaip pusè vaikinų (64,3 proc.) ir dauguma (70,9 proc.) merginų atsakè, jog pirmą kartą vartoti psichoaktyviąsias medžiagas juos paskatino bendraamžiai. 31 proc. vaikinų ir 23,4 proc. merginų pažymejjo, kad vartoti psichoaktyviąsias medžiagas juos paskatino vyresni draugai, o 4,8 proc. vaikinų ir 5,7 proc. merginų teige, jog suaugusieji.

Siekème išsiaiškinti, kokios yra 10-12 klasių mokinių psichoaktyviujų medžiagų vartojimo priežastys.

Apie pusè merginų (52,4 proc.) ir pusè vaikinų (57,0 proc.) teigè, jog psichoaktyviosios medžiagos jiems padeda atsipalaiduoti. Apie trečdaliui $(34,4$ proc.) merginų ir penktadaliui ( 21,0 proc.) vaikinų buvo

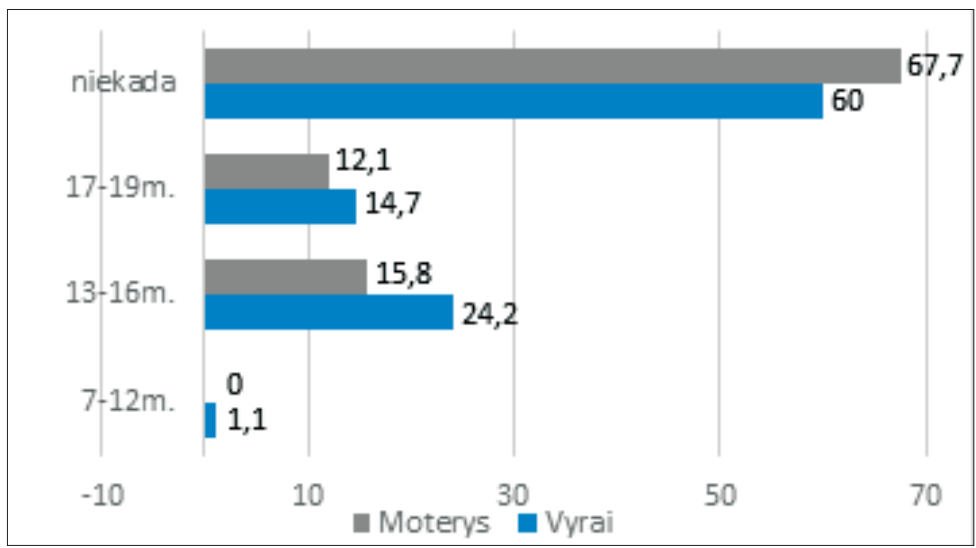

9 pav. Pirmą kartą pavartojusių narkotinių medžiagų mokinių amžius (proc.)

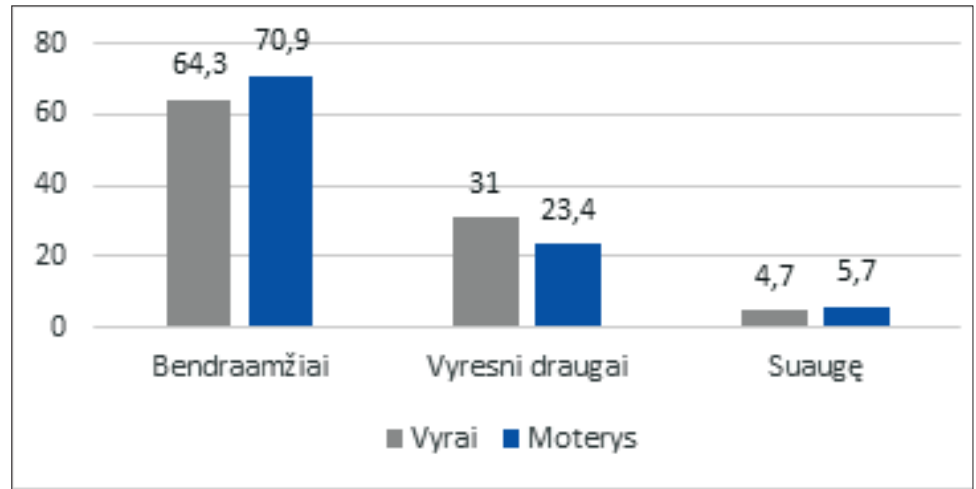

10 pav. Asmenys, pirmą kartą paskatinę mokinius vartoti psichoaktyviąsias medžiagas (proc.)

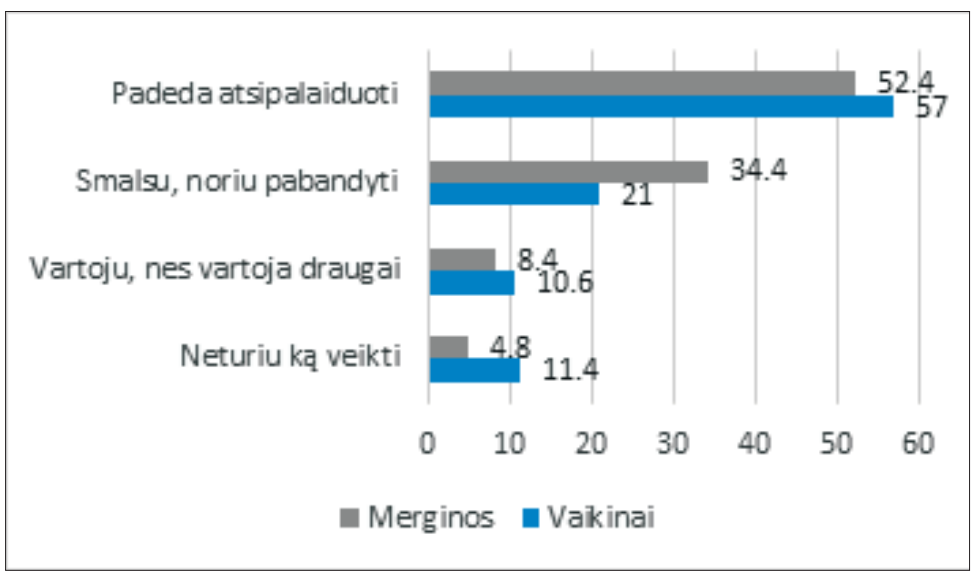

11 pav. Psichoaktyviųuu medžiagų vartojimo priežastys 
smalsu ir kilo noras pabandyti psichoaktyviụjų medžiagų. 8,4 proc. merginų ir 10,6 proc. vaikinu psichoaktyviąsias medžiagas vartojo, nes jas vartojo ir jų draugai. 4,8 proc. merginų ir 11,4 proc. vaikinų šias medžiagas vartojo, nes neturejjo ką veikti.

Mūsų tyrimo metu buvo nagrinejjama Klaipėdos miesto ir rajono 10-12 klasių mokinių rizikinga elgsena psichoaktyviujų medžiagų vartojimo kontekste. 2016 metais atlikto Lietuvos mokyklinio amžiaus vaikų gyvensenos tyrimo [27] metu nustatyta, jog 3 iš 10 vaikų Lietuvoje per pastaruosius 12 mèn. bent kartą vartojo alkoholį. Lietuvoje per pastaruosius 12 mènesių 1 iš 6 vaikų bent kartą rūkẻ tabako gaminių. Mūsų tyrimo rezultatai atskleidè, jog apie du trečdalius mokinių bent kartą rūkè per pastaruosius 12 mènesių ir apie pusè bent kartą rūkè per pastarąsias 30 dienų. Be to, dauguma 10-12 klasių mokinių vartojo alkoholinius gérimus per pastaruosius 12 mèn. ir apie pusė visų moksleivių alkoholi vartojo per pastarąsias 30 dienų. L. Rupšienès ir kt. ESPAD - 2019 tyrimo [28] duomenimis, dalis respondentų pradejjo rūkyti cigaretes 9 metų ir jaunesni, tačiau vidutiniškai cigaretès (išskyrus elektronines) buvo pradètos rūkyti 12,5 metų. Mūsų tyrimo duomenys panašūs: beveik pusė merginų ir panašiai tiek pat vaikinų pabandè rūkyti tabako gaminius ir (ar) elektronines cigaretes 13-16 metų. Beveik trečdalis vaikinų ir apie dešimtadalis merginų pirmą kartą bandè rūkyti būdami 7-12 metų. To paties ESPAD - 2019 tyrimo [28]. rezultatai atskleide, jog mokiniai pirmą kartą bandè vartoti alkoholị vidutiniškai 13,2 metų, t. y. būdami kiek vyresnio amžiaus, negu bandè rūkyti cigaretes (12,5 m.). Mūsų tyrimas atskleide, jog apie puse Klaipédos miesto ir rajono 10-12 klasių mokinių alkoholinius gèrimus pirmą kartą pavartojo būdami 13-16 m., tačiau nemaža paauglių dalis pirmą kartą alkoholio paragavo 7-12 metų. ESPAD - 2019 [28] tyrèjai nustatė, jog kanapes, kokainą (kreką) ir ekstazị mokiniai pirmą kartą bandè vartoti būdami vidutiniškai 14 metų ir vyresni, tik amfetaminus - kiek jaunesni. Ekstazị merginos bande vartoti vidutiniškai 14,5 metų, o vaikinai - 13,5 metų. Mūsų tyrimo metu buvo gauti panašūs duomenys: apie penktadalis vaikinų ir dešimtadalis merginų pirmą kartą pavartojo narkotines medžiagas būdami 13-16 metų. Vaikinai dažniau nei merginos bent kartą vartojo kanapių produktus ar kitą narkotinę medžiagą per pastaruosius 12 mėnesių ir per pastarąsias 30 dienų. Mūsų tyrimas atskleidè, jog daugiau kaip pusę vaikinų ir daugumą merginų pirmą kartą vartoti psichoaktyviąsias medžiagas paskatino bendraamžiai. Tai patvirtina mokslinèje literatūroje randamą informacija apie didelę bendraamžių itaką paauglių nuostatoms ir elgsenai. Paaugliai nurodė vartojantys psichoaktyviąsias medžiagas, manydami, kad jos padès atsipalaiduoti. Tai rodo, kad jaunimui trūksta informacijos apie psichoaktyviụjų medžiagų žalą sveikatai.
Jaunų žmonių rizikingai elgsenai būtina skirti daugiau dėmesio. Vaikų, paauglių, jaunų žmonių psichoaktyviujjų medžiagų vartojimo mažinimas, piktnaudžiavimo alkoholiu, narkotinèmis medžiagomis, tabako gaminiais, o ypač elektroninemis cigaretemis prevencija, intervencijos ịvairiais lygmenimis, prieinamumo prie psichoaktyviujjų medžiagų griežtinimas, šių medžiagų kontrolè turètų būti prioritetinis uždavinys formuojant sveikatos politiką bendruomenès, vietiniu bei nacionaliniu lygmenimis.

\section{Išvados}

1. Tabako ir (ar) elektroninių cigarečių per pastaruosius 12 mènesių nerūkè 38,4 proc., o per pastarąsias 30 dienų - nerūkè 46,2 proc. gimnazistų. Beveik pusè merginų ir panašiai tiek pat vaikinų pabandè rūkyti būdami 13-16 metų. Beveik trečdalis vaikinų ir apie dešimtadalis merginų pirmą kartą bandè rūkyti būdami 7-12 metų.

2. Alkoholio nevartojo per pastaruosius 12 mèn. tik apie dešimtadalis $(13,4$ proc.), o per pastarąsias 30 dienų $-44,4$ proc. gimnazistų. Vaikinai per pastaruosius 12 mèn. ir per pastarąsias 30 dienų reikšmingai dažniau bent kartą vartojo kokị nors alkoholinị gèrimą, nei merginos. Tyrimo rezultatai parodè, kad apie pusè vaikinų ir pusè merginų alkoholinius gèrimus pirmą kartą pavartojo būdami 13-16 m., tačiau nemaža paauglių dalis pirmą kartą alkoholio paragavo 7-12 metur.

3. Narkotinių medžiagų per pastaruosius 12 mènesių nevartojo 73,9 proc., o per pastarąsias 30 dienų $-82,9$ proc. gimnazistų. Apie penktadalis vaikinų ir dešimtadalis merginų pirmą kartą pavartojo narkotines medžiagas būdami 13-16 metų, o apie dešimtadalis vaikinų ir tiek pat merginų - būdami 17-19 metų. Vaikinai statistiškai reikšmingai dažniau nei merginos bent kartą vartojo kanapių gaminius ar kitą narkotinę medžiagą per pastaruosius 12 ménesių ir per pastarąsias 30 dienų.

4. Reikšmingų skirtumų tarp paauglių, gyvenančių mieste ir rajone (kaime), psichoaktyviųų medžiagų vartojimo aspektu nenustatyta.

5. Daugiau kaip pusè vaikinu ir dauguma ( 70,9 proc.) merginų teigè, jog pirmą kartą vartoti psichoaktyviąsias medžiagas juos paskatino bendraamžiai. Apie pusė merginų ir pusè vaikinų mano, jog psichoaktyviosios medžiagos padeda atsipalaiduoti.

\section{Literatūra}

1. Žygaitienė B., Veličkienė J. Šeimos ir mokyklos bendradarbiavimas vykdant paauglių delinkventinio elgesio prevenciją. Pedagogika, 2016;122(2):60-75.

https://doi.org/10.15823/p.2016.21

2. Health 2020: a European policy framework supporting action 
across government and society for health and wellbeing. Copenhagen: WHO Regional office for Europe 2012. http:// www. euro.who.int/_data/assets/pdf_file/0009/169803/ RC62wd09-Eng.pdf.

3. Underwood JM, Brener N, Thornton J, et al. Overview and methods for the youth risk behavior surveillance system. United States 2019. MMWR Suppl 2020; 69(1): 1-10.

https://doi.org/10.15585/mmwr.su6901a1

4. Westen D, Betan E, Defife JA. Identity disturbance in adolescence: Associations with borderline personality disorder. Development and Psychopathology 2011;23:305-313. https://doi.org/10.1017/S0954579410000817

5. Kriščiūnaitė T. Paauglių identiteto formavimosi ir santykių su tèvais sąsajos. Sisteminė literatūros apžvalga. Tarptautinis psichologijos žurnalas: biopsichosocialinis požiūris, 2014; 15:9 - 32 .

6. Liutkutė V., Štelemėkas M., Veryga A. Psichoaktyvių medžiagų vartojimo prevencijos organizavimas bendruomenèje. Metodinis leidinys. Kaunas: LSMS, 2014.

7. Janonienė R., Radzevičiūtė I., Ivanauskienė R., Veryga A. Trumposios intervencijos: alkoholio vartojimo ịpročių patikros ir pagalbos teikimo rekomendacijos. Vilnius: Higienos institutas, 2016.

8. Strukčinskienė B., Strazdienė N., Rauckienė-Michaelsson A., Strukčinskaitė V., Tervydytė D., Griškonytė E., Griškonis S. Universiteto studentų gyvensena: alkoholio vartojimo aspektai. Sveikatos mokslai, 2018; 28 (7): 36-40.

https://doi.org/10.5200/sm-hs.2018.087

9. Coren E, Hossain R, Pardo Pardo J, Bakker B. Interventions for promoting reintegration and reducing harmful behaviour and lifestyles in street-connected children and young people. Cochrane Database of Systematic Reviews 2016; (1):1-128. Art. No.: CD009823.

https://doi.org/10.4073/csr.2016.5

10. Hossain R, Coren E. Service engagement in interventions for street-connected children and young people: a summary of evidence supplementing a recent Cochrane-Campbell review. Child Youth Care Forum 2014;44(3):451-470.

https://doi.org/10.1007/s10566-014-9286-6

11. Patton R, Slesnick N, Bantchevska D, Guo X, Kim Y. Predictors of follow-up completion among runaway substance-abusing adolescents and their primary caretakers. Community Mental Health Journal 2011;47:220-226.

https://doi.org/10.1007/s10597-009-9281-9

12. Lightfoot M, Stein JA, Tevendale H, Preston K. Protective factors associated with fewer multiple problem behaviors among homeless/runaway youth. Journal of Clinical Child Adolescent Psychology 2011;40(6):878-889.

https://doi.org/10.1080/15374416.2011.614581

13. Häggman-Laitila A, Toivonen K, Puustelli A, Salokekkilä P. Do aftercare services take young people's health behaviour into consideration? A retrospective document analysis from
Finland. J Pediatr Nurs 2020;55:134-140.

https://doi.org/10.1016/j.pedn.2020.08.005

14. Rosenbaum GM, Hartley CA, Philos Trans R. Developmental perspectives on risky and impulsive choice. Soc Lond B Biol Sci 2019;374(1766): 20180133.

https://doi.org/10.1098/rstb.2018.0133

15. Glasner J, Baltag V, Ambresin AE. Previsit multidomain psychosocial screening tools for adolescents and young adults: A systematic review. J Adolesc Health 2021; 68(3): 449-459. https://doi.org/10.1016/j.jadohealth.2020.10.003

16. Foulkes L, Leung JT, Fuhrmann D, Knoll LJ, Blakemore SJ. Age differences in the prosocial influence effect. Dev Sci 2018; 21(6): e12666.

https://doi.org/10.1111/desc.12666

17. Escobar-Chaves SL, Anderson CA. Media and risky behaviors. Future Child 2008;18(1): 147-180. https://doi.org/10.1353/foc. 0.0007

18. Tolou-Shams M, Brown L K, Marshall BDL, et al. The behavioral health needs of first-time offending justice-involved youth: Substance use, sexual risk and mental health. Child Adolesc Subst Abuse 2019; 28(5): 291-303. https://doi.org/10.1080/1067828X.2020.1774023

19. Hong JS, Kim DH, Hunter SC, et al. Racial/ethnic bullying subtypes and alcohol, tobacco, and marijuana use among US adolescents. Racial Ethn Health Disparities 2021. https://doi.org/10.1007/s40615-021-01081-w

20. Eck RH, Trangenstein PJ, Siegel M, Jernigan DH. Companyspecific revenues from underage drinking. J Stud Alcohol Drugs 2021; 82(3):368-376. https://doi.org/10.15288/jsad.2021.82.368

21. Jackson C, Geddes R, Haw S, Frank J. Interventions to prevent substance use and risky sexual behaviour in young people: A systematic review. Addiction 2012;107(4): 733-747. https://doi.org/10.1111/j.1360-0443.2011.03751.x

22. Jones CB, Meier MH, Corbin WE, Chassin L. Adolescent executive cognitive functioning and trait impulsivity as predictors of young-adult risky drinking and alcohol-related problems. Psychol Addict Behav $2021 ; 35(2): 187-198$. https://doi.org/10.1037/adb0000636

23. Hall WD, Patton G, Stockings E, Weier M, Lynskey M, Morley KI, Degenhardt L. Why young people's substance use matters for global health. Lancet Psychiatry 2016; 3(3): 265-279. https://doi.org/10.1016/S2215-0366(16)00013-4

24. Howard J, Ali H, Robins L. Alcohol, cannabis and amphetamine-type stimulants use among young Pacific Islanders. Drug Alcohol Rev 2011; 30(1): 104-110. https://doi.org/10.1111/j.1465-3362.2010.00272.x

25. Strukčinskienė B., Raistenskis J., Radžiuvienė R., Strukčinskaitė V. Vaikų ir paauglių sveikos gyvensenos veiksniai: fizinio aktyvumo ypatumai. Klaipėda: Druka, 2018.

26. Stankūnas M., Veryga A., Jakubauskienė M. ir kt. Sveikatos 
netolygumų mažinimo praktinès rekomendacijos. Kaunas: UAB Arx reklama, 2017.

27. Liuima V., Valintėlienè R., Jociutė A. Mokyklinio amžiaus vaikų gyvensenos tyrimas. $2016 \mathrm{~m}$. rodiklių suvestiné-ataskaita. Vilnius: Higienos institutas, 2016.

28. Rupšienė L., Saveljeva R., Šutinienė I., ESPAD - 2019: Alkoholio ir kitų psichoaktyviųjų medžiagų vartojimas Lietuvoje. Tyrimo ataskaita, Vilnius: LETA, ŠMSM, 2020.

\section{RISKY BEHAVIOURS IN $10^{\text {TH }}$ TO $12^{\text {TH }}$ GRADE SCHOOLCHILDREN AT KLAIPEDA CITY AND KLAIPEDA DISTRICT:}

PSYCHOACTIVE SUBSTANCES CONSUMPTION

N. Strazdienė, B. Strukčinskienė, V. Strukčinskaitė,

I. Pačiauskaitė, M. Prokofjeva, S. Griškonis

Keywords: Klaipeda city, Klaipeda district, schoolchildren, teenagers, young people, risky behaviour, psychoactive substances.

\section{Summary}

Many diseases and disorders are caused by risky behaviours that expose danger for human health, well-being, future development, and success. It is especially important that new risky experiences do not lead to risky behaviours in young people. It is a priority issue to develop healthy lifestyle habits in teenage schoolchildren.
The article analyses the risky behaviour of Klaipeda city and Klaipeda district teenagers with focus on psychoactive substances (tobacco products and/or electronic cigarettes, alcohol, and drugs) consumption. Quantitative research strategy was chosen, and a written survey was applied. 260 students of Klaipeda city and Klaipeda district in grades 10 to 12 , aged 16 to 19 years participated in the study. SPSS program (version 23.0) was used for statistical data analysis. The Chi-square $(\chi 2)$ criterion was used to check statistical significance. Data were statistically significant when $p<0.05$. The results of the study showed that the majority of teenagers started using psychoactive substances, when they were 13-16 years old, and part of teenagers - when they were 7-12 years old. The study revealed that, most teenagers did not used drugs but used alcohol, and almost half of respondents - smoked. Boys were significantly more likely to use alcohol and drugs that of girls. There were no significant differences in psychoactive substances consumption between urban and rural respondents. Teenage schoolchildren were encouraged by their peers to use psychoactive substances. About half of teenagers self-reported that the consumption of psychoactive substances help them to relax.

Correspondence to: n.strazdiene@gmail.com Gauta 2021-09-28

\section{KVIEČIAME PRENUMERUOTI „SVEIKATOS MOKSLŲ“ ŽURNALĄ 2022 METAIS!}

Žurnalas „Sveikatos mokslai“ (Index Copernicus, EBSCO host (Academic Search Complete), Gale (Academic OneFile), ProQuest (Ulrich's, Summon), Australia (ERA) 2012 Journal List (ERA ID 34962) skirtas visų specialybiu gydytojams, slaugytojams ir kitiems specialistams, spausdina mokslinius straipsnius lietuvių, anglų kalbomis. Reikalavimai straipsniams atitinka mokslo leidiniams keliamus reikalavimus. Žurnalas spaudos kioskuose neparduodamas. Žurnalą, kuris leidžiamas kartą per du mėnesius, galima užsiprenumeruoti visuose Lietuvos pašto skyriuose ir internetu: www.prenumeruok.It

Prenumeratos kaina nesikeičia: visiems metams - 36 EUR, šešiems mėnesiams - 18 EUR, keturiems mẻnesiams - 12 EUR, dviem mẻnesiams - 6 EUR. Prenumeratos kodas: 5348.

Žurnalo autoriams straipsnių spausdinimas ir jų internetinè sklaida mokama.

Redakcija 